\title{
Implementasi Metode AHP dalam Menentukan Penerima Beasiswa Komite Sekolah
}

\author{
Asnawati $^{1, *}$, Prahasti $^{2}$, Liza Yulianti ${ }^{2}$ \\ ${ }^{1}$ Fakultas Ilmu Komputer, Prodi Sistem Informasi, Universitas Dehasen Bengkulu, Bengkulu, Indonesia \\ ${ }^{2}$ Fakultas Ilmu Komputer, Prodi Informatika, Universitas Dehasen Bengkulu, Bengkulu, Indonesia \\ Email: 1," asnawati@unived.ac.id, ${ }^{2}$ prahasti.mona82@gmail.com, ${ }^{3}$ liza.yulianti@unived.ac.id \\ Email Penulis Korespondensi: asnawati@unived.ac.id
}

\begin{abstract}
Abstrak-Penghargaan bagi seorang siswa berprestasi oleh sekolah melalui komite sekolah perlu diberikan dalam upaya untuk meningkatkan motivasi dan semangat belajar siswa. Melalui pemberian beasiswa pembebasan uang komite diharapkan siswa dapat terus meningkatkan prestasinya. Siswa penerima beasiswa komite sekolah merupakan siswa terbaik yang dinilai berdasarkan kriteri-kriteria tertentu. Kriteria penerima beasiswa telah ditentukan oleh SMKN 2 Kota Bengkulu, namun demikian penyeleksian masih menggunakan sistem manual. Penggunaan sistem tersebut memiliki kendala diantarnya membutuhkan waktu yang lama dalam pengelolaan. Disamping itu, masih ditemukan subjektiftas dalam penilaian. Dibutuhkan alternatif sistem yang lebih baik dalam pengelolaan penerima beasiswa komite sekolah. Penggunaan metode Analytical Hierarchy Process (AHP) dalam Sistem Pendukung Keputusan (SPK) akan memberikan hasil terbaik sehingga akan diperoleh siswa yang benar-benar layak mendapatkan beasiswa. Sistem Pendukung Keputusan di SMKN 2 Kota Bengkulu dalam menentukan penerima beasiswa komite sekolah berdasarkan kriteria yaitu nilai rapor, prestasi akademik dan prestasi non akademik dengan bobot penilaian yang telah ditentukan. Hasil dari perhitungan diperoleh nilai akhir berdasarkan perangkingan satu sampai tiga diperoleh nilai 0,3925, 0,2150 dan rangking 3 dengan nilai akhir 0,1434. Berdasarkan hasil perangkingan yang ada telah menghasilkan penerima beasiswa yang betul-betul sesuai dengan kriteria yang telah ditetapkan.
\end{abstract}

Kata Kunci: Sistem Pendukung Keputusan; Beasiswa; Komite Sekolah; AHP.

Abstract-Award for an outstanding student by the school through the school committee needs to be given in an effort to increase student motivation and enthusiasm for learning. Through the awarding of committee money exemption scholarships, students are expected to continue to improve their performance. Students who receive school committee scholarships are the best students who are judged based on certain criteria. The criteria for scholarship recipients have been determined by SMKN 2 Bengkulu City, however, the selection is still using a manual system. The use of this system has constraints in that it takes a long time to manage. In addition, subjectivity was still found in the assessment. A better alternative system is needed in the management of school committee scholarship recipients. The use of the Analytical Hierarchy Process (AHP) method in the Decision Support System (SPK) will give the best results so that students who really deserve scholarships will be obtained. The Decision Support System at SMKN 2 Bengkulu City in determining recipients of school committee scholarships is based on criteria, namely report card scores, academic achievement and non-academic achievements with a predetermined weighting rating. The results of the calculation obtained the final value based on rank one to three obtained values of 0.3925 , 0.2150 and rank 3 with a final value of 0.1434 . Based on the results of the existing ranking, it has produced scholarship recipients who actually meet the predetermined criteria.

Keywords: Decision Support System; Scholarships; School Committee; AHP

\section{PENDAHULUAN}

Beasiswa adalah bantuan untuk membantu orang terutama bagi yang masih sekolah atau kuliah agar mereka dapat menyelesaikan tugasnya dalam rangka mencari ilmu pengetahuan hingga selesai. Bantuan ini biasanyanya berbentuk dana untuk menunjang biaya atau ongkos yang harus dikeluarkan oleh anak sekolah atau mahasiswa selama menempuh masa pendidikan ditempat belajar yang diinginkan [1]. Pemberian beasiswa dilakukan oleh suatu instansi maupun lembaga pendidikan yang diberikan kepada pelajar ataupun siswa yang berprestasi maupun siswa yang berprestasi dan kurang mampu dari bidang ekonomi. Beasiswa yang diberikan kepada peserta didik maupun siswa dapat berupa: 1) beasiswa penghargaan, 2) beasiswa bantuan, 3) beasiswa bagi atlet berprestasi, 4) beasiswa pendidikan. Pemberian beasiswa bagi siswa dalam lingkungan pendidikan pada jenjang pendidikan sekolah menengah kejuruan dilakukan oleh pihak sekolah, kementerian pendidikan, lembaga maupun instansi negeri maupun swasta yang peduli dengan pendidikan maupun komite sekolah.

Komite Sekolah adalah lembaga mandiri yang beranggotakan orangtua/wali peserta didik, komunitas sekolah, serta tokoh masyarakat yang peduli pendidikan [2]. Bagi siswa pemberian beasiswa akan memberikan suatu dorongan motivasi meningkatkan kemampuan dirinya untuk terus berprestasi dan mempertahankan prestasi yang telah diraihnya. Selain itu, untuk memperoleh bantuan beasiswa, seorang siswa harus memiliki tanggung jawab dan prestasi baik akademik maupun non akademik yang dapat membawa nama baik lembaga pendidikan dimana siswa tersebut menempuh pendidikannya.

Kemampuan siswa dalam meraih prestasi, dilakukan melalui ketekunan maupun keuletan dalam belajar sehingga sumber daya yang ada dalam dirinya akan terus terasah. Siswa yang memiliki prestasi akan membawa kemajuan bagi lembaga pendidikan. Disisi lain, bagi siswa berprestasi, siswa tersebut memiliki peluang yang lebih besar dalam melanjutkan pendidikan yang lebih tinggi atau memperoleh pekerjaan sesuai dengan program keahlian yang milikinya. Komite sekolah beserta lembaga pendidikan harus berusaha untuk menjaga kualitas 
sekolah dan prestasi yang diimiliki oleh peserta didiknya melalui pemberian bantuan beasiswa. Untuk mendapatkan bantuan beasiswa, diperlukan penilaian yang betul-betul akurat sehingga penerima beasiswa merupakan siswa yang betul-betul berhak mendapatkannya. Melalui penilaian berupa kriteria-kriteria yang telah ditetapkan, diharapkan pemberian beasiswa tepat sasaran dan dimanfaatkan dengan sebaik-baiknya oleh siswa penerima beasiswa.

SMKN 2 Kota Bengkulu merupakan salah satu sekolah menengah kejuruan di bawah naungan Dinas Pendidikan dan Kebudayaan Provinsi Bengkulu. Dalam menentukan pemberian beasiswa komite sekolah, SMKN 2 Kota Bengkulu sebelumnya memiliki kesulitan dan kendala. Dimana, kendala tersebut diantaranya adalah dalam hal pengelolaan data calon penerima beasiswa. Dalam pelaksanaannya, dibutuhkan waktu yang lama dalam penyeleksian sehingga siswa penerima beasiswa juga menunggu dalam jangka waktu yang lama untuk mendapatkan kepastian apakah sebagai penerima atau tidak. Kendala lain, masih ditemukannya subjektifitas dalam penyeleksian penerima beasiswa, belum adanya standar yang baku dalam penilaian dan criteria yang disyaratkan dalam proses penyeleksian penerima beasiswa serta masih belum adanya keterbukaaan dan transparan dalam penyeleksian. Oleh sebab itu, dibutuhkan suatu perbaikan sistem yang lebih baik dan lebih transparan dalam penyeleksian dan pengolahan data siswa calon penerima beasiswa melalui sebuah Sistem Pendukung Keputusan (SPK). Melalui perbaikan sistem tersebut dapat memberikan solusi terbaik berdasarkan kriteria-kriteria yang telah ditentukan oleh pihak sekolah.

Penggunaan Sistem Pendukung Keputusan (SPK) saat ini telah diterapkan dalam membantu berbagai pihak terutama bagi seorang pimpinan dalam mendapatkan keputusan terbaik dari berbagai alternatif yang ditawarkan berdasarkan kriteria yang telah ditentukan. Sistem Pendukung Keputusan (SPK) yang ada saat ini telah digunakan diantaranya, Penelitian serupa yang dilakukan oleh Budisaputro menggunakan metode AHP dalam proses pengambilan keputusan penerima beasiswa [3] Sistem Pendukung Keputusan penentuan lokasi wisata [4], Sistem Pendukung Keputusan pemilihan perumahan [5], Sistem Pendukung Keputusan (SPK) pemilihan karyawan terbaik [6] dan Sistem Pendukung Keputusan untuk kenaikan jabatan pegawai [7]. Metode AHP-Topsis untuk rekomendasi Penerima Beasiswa [8]. Sistem Pendukung Keputusan Untuk Menentukan Beasiswa [9], Sistem Pendukung Keputusan Pemilihan Program Studi [10], Penentuan Dosen Terbaik Menggunakan Metode Analytical Hierarchy Process (AHP) dan For Order By Similarity To Ideal Solution (TOPSIS) [11].

\section{METODOLOGI PENELITIAN}

\subsection{Tahapan Penelitian}

Penelitian dilaksanakan di SMKN 2 Kota Bengkulu dengan pendekatan yang sismatis dan dijalankan secara berutan atau waterfall (air terjun) dimulai dari tahapan analisis kebutuhan sistem lalu menuju tahap desain sistem, implementasi, integrasi dan pengujian serta pemeliharaan seperti terlihat pada bagan dibawah ini:

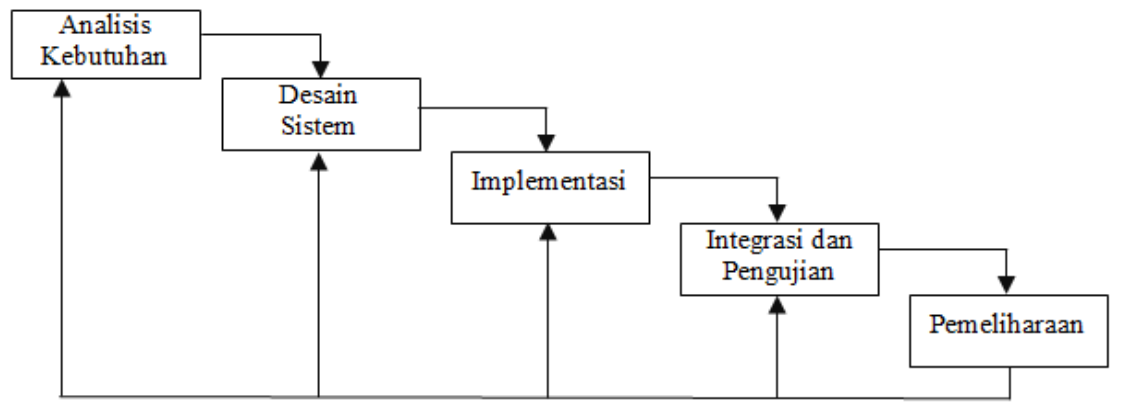

Gambar 1. Bagan Metode Waterfall

Sementara itu, untuk mencapai tujuan penelitian sesuai yang diinginkan dibutuhkan metode pengumpulan data terdiri dari:

a. Observasi

Pada tahapan pengumpulan data ini, dilakukan pengamatan terhadap hal-hal yang mendukung pelaksanaan penelitian dengan cara mengamati dan mencatat pelaksanaan seleksi siswa penerima beasiswa komite.

b. Wawancara

Metode wawancara dilaksanakan untuk mendapatkan gambaran secara utuh dan mengetahui sistem yang sebelumnya dilaksanakan penyeleksian siswa penerima beasiswa beserta kriteria-kriteria serta bobot kriteria yang ditentukan oleh pihak sekolah.

c. Studi Pustaka

Metode ini digunakan untuk mendukung kajian teori melalui sumber referensi yang berhubungan penelitian yang dilakukan baik melalui buku, jurnal maupun kegiatan lain yang berhubungan dengan studi pustaka. 


\subsection{Sistem Pendukung Keputusan (SPK)}

DSS biasanya digunakan untuk mendukung solusi atas suatu masalah atau untukmengevaluasi suatu peluang. DSS yang seperti itu disebut aplikasi DSS. Aplikasi DSS digunakan dalam pengambilan keputusan dengan menggunakan Computer Based Information Systems (CBIS) yang fleksibel, interaktif, dan dapat diadaptasi,yang dikembangkan untuk mendukung solusi atas masalah manajemen spesifikyang tidak terstruktur. Aplikasi DSS ini menggunakan data, memberikan antarmuka pengguna yang mudah, dan dapat menggabungkan pemikiran pengambil keputusan. DSS tidak dimaksudkan untuk mengotomatisasikan pengambil keputusan, tetapi memberikan perangkat interaktif yang memungkinkan pengambil keputusan untuk melakukan berbagai analisis menggunakan model-model yang tersedia [12]. Sistem Pendukung Keputusan adalah sistem informasi interaktif yang menyediakan informasi, pemodelan, dan pemanipulasian data. Sistem pendukung keputusan digunakan untuk membantu pengambilan keputusan dalam situasi yang semi terstruktur dan situasi yang tidak terstruktur [13]. Sistem Pendukung Keputusan biasanya dibangun untuk mendukung solusi atau masalah atau untuk suatu peluang [14].

\subsection{Analytical Hierarchy Process (AHP)}

Dikembangkan oleh Prof. Thomas Lorie Saaty dari Wharton Business School awal tahun 1970. Metode ini gunakan untuk mencari urutan atau ranking prioritas dari berbagai alternatif dalam pemecahan masalah [15]. Metode AHP merupakan suatu model pendukung keputusan dikembangkan oleh Thomas L. Saaty. Model pendukung keputusan ini akan menguraikan masalah multi faktor atau multi kriteria yang kompleks menjadi suatu hirarki, menurut Saaty dalam Supriyadi (2018), hirarki didefinisikan sebagai suatu representasi dari sebuah permasalahan yang kompleks dalam suatu struktur multilevel dimana level pertama adalah tujuan, yang diikuti level faktor, kriteria, subkriteria, dan seterusnya kebawah hingga level terakhir dari alternatif. Dengan hirarki, suatu masalah yang kompleks dapat diuraikan kedalam kelompok-kelompoknya yang kemudian diatur menjadi suatu bentuk hirarki sehingga permasalahan akan tampak lebih terstruktur dan sistematis. Penggunaan metode AHP dalam sistem pendukung keputusan dilakukan berdasarkan prinsip penyederrhanaan suatu persoalan kompleks yang tidak terstruktur, stratejik dan dinamik menjadi bagian-bagian, serta menata dalam suatu hirarki. Selanjutnya, tingkat kepentinganya setiap variabel diberi nilai numerik secara subjektif tentang arti pentingvariabel tersebut secara relatif di bandingkan dengan variable lain. Dari berbagai pertimbangan tersebut kemudian di lakukan sintesa untuk menetapkan variable yang memiliki prioritas tinggidan berperan untuk mempengaruhi hasil pada sistem tersebut. Metode AHP memiliki kelebihan dalam mengambil suatu keputusan dengan cara membandingkan secara berpasangan setiap kriteria yang dimiliki oleh suatu permasalahan sehingga didapat suatu bobot nilai dari kepentingan tiap kriteria-kriteria yang ada [16].

Tabel 1. Skala Penilaian Perbandingan Berpasangan Metode AHP

\begin{tabular}{cl}
\hline $\begin{array}{c}\text { Intensitas } \\
\text { Kepentingan }\end{array}$ & \multicolumn{1}{c}{ Keterangan } \\
\hline 1 & Kedua elemen sama pentingnya \\
3 & Elemen yang satu sedikit lebih penting dari pada elemen yang lainya \\
5 & Elemen yang satu lebih penting dari pada yang lainya \\
7 & Satu elemen jelas lebih mutlak penting dari pada elemen lainya \\
9 & Satu elemen mutlak penting dari pada elemen lainya \\
$2,4,6,8$ & Nilai-nilai antara dua nilai pertimbangan-pertimbangan yang berdekatan \\
\hline
\end{tabular}

Langkah-langkah penyelesaian Sistem Pendukung Keputusan dengan menggunakan metode Analytical Hierarchy Process (AHP) yaitu:

a. Menyusun hierarki.

b. Menilai kriteria dan alternatif.

c. Memilih prioritas.

d. Menentukan nilai konsistensi logis

e. Menentukan nilai indeks konsistensi (CI), dengan rumus yang digunakan sebagai berikut:

(a). $\quad C I=\frac{\lambda \max -1}{n-1}$

Keterangan:

$\mathrm{N}=$ banyaknya kriteria

f. Menentukan rasio konsistensi (CR), dengan rumus sebagai berikut:

(b). $\quad C R=\frac{C I}{R I}$

Keterangan

$\mathrm{CR}=$ Rasio Konsistensi

$\mathrm{CI}=$ Indeks Konsistensi

$\mathrm{RI}=$ Indeks Random Konsistensi

g. Memeriksa konsistensi hierarki. 
Jika hasil perhitungan nilai rasio konsistensi lebih dari 10\%, maka harus diperbaiki atau dihitung ulang. Tapi jika rasio konsistensi kurang atau sama dengan 0,1 maka dapat dinyatakan benar nilai perhitungannya.

\subsection{Beasiswa}

Beasiswa dapat diberikan oleh lembaga pemerintah, perusahaan ataupun yayasan. Pemberian beasiswa dapat dikategorikan pada pemberian cuma-cuma ataupun pemberian dengan ikatan kerja (biasa disebut ikatan dinas) setelah selesainya pendidikan. Lama ikatan dinas ini berbeda-beda, tergantung pada lembaga yang memberikan beasiswa tersebut. beasiswa juga banyak diberikan kepada perkelompok (group) misalnya ketika ada event perlombaan yang diadakan oleh lembaga pendidikan, dan salah satu hadiahnya adalah beasiswa. Beasiswa dapat diartikan sebagai bentuk penghargaan yang diberikan kepada individu agar dapat melanjutkan pendidikan ke jenjang yang lebih tinggi, penghargaan itu dapat berupa akses tertentu pada suatu instansi atau penghargaan berupa bantuan keuangan [17].

\section{HASIL DAN PEMBAHASAN}

Berdasarkan analisis sistem aktual yang ada di SMKN 2 Kota Bengkulu, ternyata penyeleksian siswa penerima beasiswa komite sekolah belum terintegrasi ke dalam suatu sistem berbasis komputer sehingga menimulkan kendala keterlambatan dan waktu yang lama dalam pengelolaan. Disamping itu, masih adanya rasa subjektifitas yang dilakukan dan dilaporkan kepada kepala sekolah sehingga penerima beasiswa belum sepenuhnya sesuai dengan harapan. Metode yang digunakan dalam pembuatan Sistem Pendukung Keputusan (SPK) penerima beasiswa komite sekolah adalah metode Analytical Hierarchy Process (AHP) dengan kriteria adalah: 1) Nilai raport siswa, 2) Prestasi akademik siswa dan 3) Prestasi non akademik siswa.

Adapun tahapan yang dilakukkan dalam pembuatan Sistem Pendukung Keputusan (SPK) terlebih dahulu dilakukan penyeleksian melalui criteria dan pemberian bobot masing-masing criteria, seperti terlihat pada penggunaan metode Analytical Hierarchy Process (AHP) berikut

a. Pembuatan bobot masing-masing kriteria

1) Nilai Rapor

Tabel 2. Kriteria dan Bobot Nilai Rapor

\begin{tabular}{cc}
\hline Range & Pembobotan \\
\hline Nilai Rerata Raport $<=65$ & 1 \\
Nilai Rerata Raport $<=75$ & 2 \\
Nilai Rerata Raport $<=85$ & 3 \\
Nilai Rerata Raport $>85$ & 4 \\
\hline
\end{tabular}

2) Prestasi Akademik

Tabel 3. Kriteria dan Bobot Nilai Akademik

\begin{tabular}{cc}
\hline Range & Pembobotan \\
\hline Kota $<=65$ & 1 \\
Provinsi $<=75$ & 2 \\
Nasional $>75$ & 3 \\
\hline
\end{tabular}

3) Presasti Non Akademik

Tabel 4. Kriteria dan Bobot Nilai Non Akademik

\begin{tabular}{cc}
\hline Range & Pembobotan \\
\hline Kota $<=65$ & 1 \\
Provinsi $<=75$ & 2 \\
Nasional $>75$ & 3 \\
\hline
\end{tabular}

4) Pembuatan Matrik Perbandingan Antar Kriteria

Tabel 5. Matrik Perbandingan Kriteria

\begin{tabular}{cccc}
\hline Antar Kriteria & NR & NA & NNA \\
\hline NR & 1 & 5 & 7 \\
NA & 0,2 & 1 & 5 \\
NNA & 0,1429 & 0,2 & 1 \\
\hline
\end{tabular}

5) Pembuatan Nilai Matrik Perbandingan Kriteria 
JURNAL MEDIA INFORMATIKA BUDIDARMA

Volume 5, Nomor 2, April 2021, Page 746-755

ISSN 2614-5278 (media cetak), ISSN 2548-8368 (media online)

Available Online at https://ejurnal.stmik-budidarma.ac.id/index.php/mib

DOI 10.30865/mib.v5i2.2918

Tabel 6. Nilai Matrik Perbandingan Kriteria

\begin{tabular}{cccccc}
\hline & NR & NA & NNA & Jumlah & Prioritas \\
\hline NR & 0,7447 & 0,8065 & 0,5385 & 2,089 & 0,696 \\
NA & 0,1489 & 0,1613 & 0,3846 & 0,694 & 0,231 \\
NNA & 0,0164 & 0,0323 & 0,0769 & 0,215 & 0,071 \\
\hline
\end{tabular}

6) Rasio Konsistensi

Tabel 7. Rasio Konsistensi

\begin{tabular}{cccc}
\hline Perbandingan & Jumlah & Prioritas & Hasil \\
\hline NR & 2,3576 & 0,6965 & 3,0541 \\
NA & 0,7302 & 0,2316 & 0,9618 \\
NNA & 0,2177 & 0,1719 & 0,2895 \\
& Rata-Rata & & 1,4352 \\
\hline
\end{tabular}

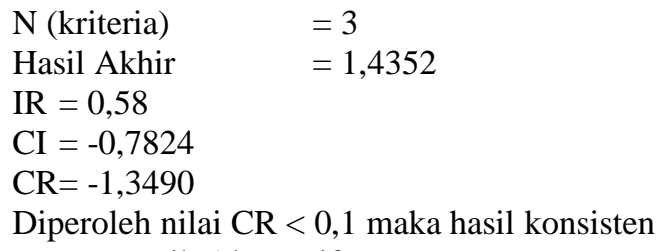

b. Perhitungan Matrik Alternatif

1) Matrik Perbandingan Alternatif Nilai Rapor

Tabel 8. Matrik Perbandingan Alternatif Rapor

\begin{tabular}{ccccc}
\hline Nama & DK & \multicolumn{2}{c}{ IKJ } & MH \\
\hline DK & 1 & & 5 & 7 \\
IKJ & 0,2 & & 1 & 5 \\
MH & 0,1429 & & 0,2 & 1 \\
\hline Jumlah & 1,3429 & & 6,2 & 13 \\
\hline Hasil perbandingan & & \multicolumn{2}{c}{ MH } & Prioritas \\
\hline Nama & DK & IKJ & 0,5385 & 0,67371 \\
DK & 0,7447 & 0,8065 & 0,3846 & 0,2126 \\
IKJ & 0,1489 & 0,1613 & 0,0769 & 0,0506 \\
MH & 0,1064 & 0,0323 & 0,0 & \\
\hline
\end{tabular}

2) Matrik Perbandingan Alternatif Nilai Akademik

Tabel 9. Matrik Perbandingan Alternatif Akademik

\begin{tabular}{ccccc}
\hline Nama & DK & IKJ & MH \\
\hline DK & 1 & & 7 & 5 \\
IKJ & 0,1429 & & 1 & 3 \\
MH & 0,2 & & 0,3 & 1 \\
\hline Jumlah & 1,3429 & & 8,3333 & 9 \\
\hline Hasil Perbandingan & \multicolumn{3}{c}{ MH } & Prioritas \\
\hline \multicolumn{7}{c}{} & DK & IKJ & MH & 0,6427 \\
DK & 0,7447 & 0,8400 & 0,5556 & 0,1976 \\
IKJ & 0,1064 & 0,1200 & 0,3333 & 0,0600 \\
MH & 0,1489 & 0,0400 & 0,1111 & \\
\hline
\end{tabular}

3) Matrik Perbandingan Alternatif Nilai Non Akademik

Tabel 10. Matrik Perbandingan Alternatif Non Akademik

\begin{tabular}{|c|c|c|c|c|}
\hline Nama & DK & IKJ & & $\mathrm{MH}$ \\
\hline DK & 1 & 4 & & 4 \\
\hline IKJ & 0,2 & 1 & & 3 \\
\hline $\mathrm{MH}$ & 0,25 & 0,33 & & 1 \\
\hline Jumlah & 1,45 & 6,3333 & & 8 \\
\hline \multicolumn{5}{|c|}{ Hasil Perbandingan } \\
\hline & DK & IKJ & $\mathrm{MH}$ & Prioritas \\
\hline DK & 0,6897 & 0,7895 & 0,5000 & 0,6248 \\
\hline
\end{tabular}


JURNAL MEDIA INFORMATIKA BUDIDARMA

Volume 5, Nomor 2, April 2021, Page 746-755

ISSN 2614-5278 (media cetak), ISSN 2548-8368 (media online)

Available Online at https://ejurnal.stmik-budidarma.ac.id/index.php/mib DOI 10.30865/mib.v5i2.2918

\begin{tabular}{ccccc}
\hline IKJ & 0,1379 & 0,1579 & 0,3750 & 0,2099 \\
MH & 0,1724 & 0,0526 & 0,1250 & 0,0656 \\
\hline
\end{tabular}

4) Hasil Bobot Penilaian

Tabel 11. Bobot penilaian

\begin{tabular}{cccc}
\hline \multirow{2}{*}{ Alternatif } & Raport & $\begin{array}{c}\text { Kriteria } \\
\text { Akademik }\end{array}$ & $\begin{array}{c}\text { Non } \\
\text { Akademik }\end{array}$ \\
\cline { 2 - 4 } & 0.6965 & 0,2316 & 0,0719 \\
\hline DK & 0,6248 & 0,3113 & 0,3332 \\
IKJ & 0,2099 & 0,1923 & 0,1984 \\
MH & 0,0656 & 0,1633 & 0,1440 \\
\hline
\end{tabular}

Hitung nilai prepensi dari masing-masing Siswa berdasarkan masing-masing kriteria

$\mathrm{DK}=(0,6248 * 0.6965)+(0,3113 * 0,2316)+$

$(0,3332 * 0,0719)$

$=(0,4352)+(0,0721)+(0,239)$

$=0,5313$

IKJ $=(0,2099 * 0.6965)+(0,1923 * 0,2316)+$

$(0,1984 * 0,0719)$

$=(0,1462)+(0,0445)+(0,0143)$

$=0,2050$

$\mathrm{MH}=(0,0656 * 0.6965)+(0,1633 * 0,2316)+$

$(0,1440 * 0,0719)$

$=(0,0457)+(0,0378)+(0,0104)$

$=0,0938$

Tampilan menu input data siswa dari Sistem Pendukung Keputusan (SPK) menggunakan metode Analytical Hierarchy Process (AHP) seperti terlihat pada gambar 1.

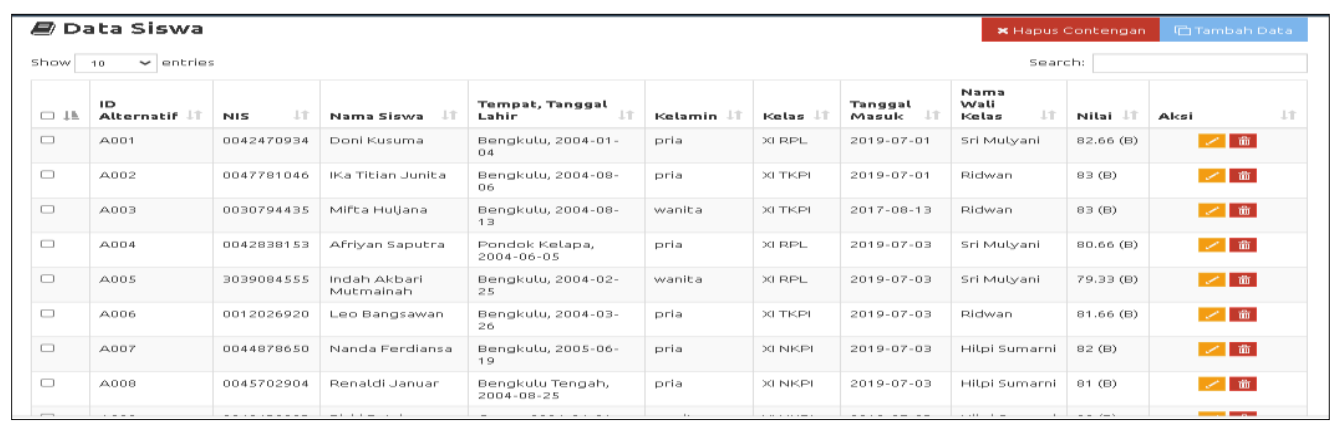

Gambar 2. Tampil Data Siswa

Seperti terlihat pada gambar 2 tersebut diatas, merupakan tampilan halaman yang digunakan untuk menampilkan daftar siswa yang telah dimasukkan ke dalam sistem. Disamping itu, terdapat tombol Tambah Data, Edit Data dan Hapus Data yang memilki fungsi Tambah data untuk menambahkan data-data siswa ke dalam sistem, Edit Data digunakan untuk memperbaiki data yang salah dan Hapus Data yang digunakan untuk menghapus data yang ada di sistem.

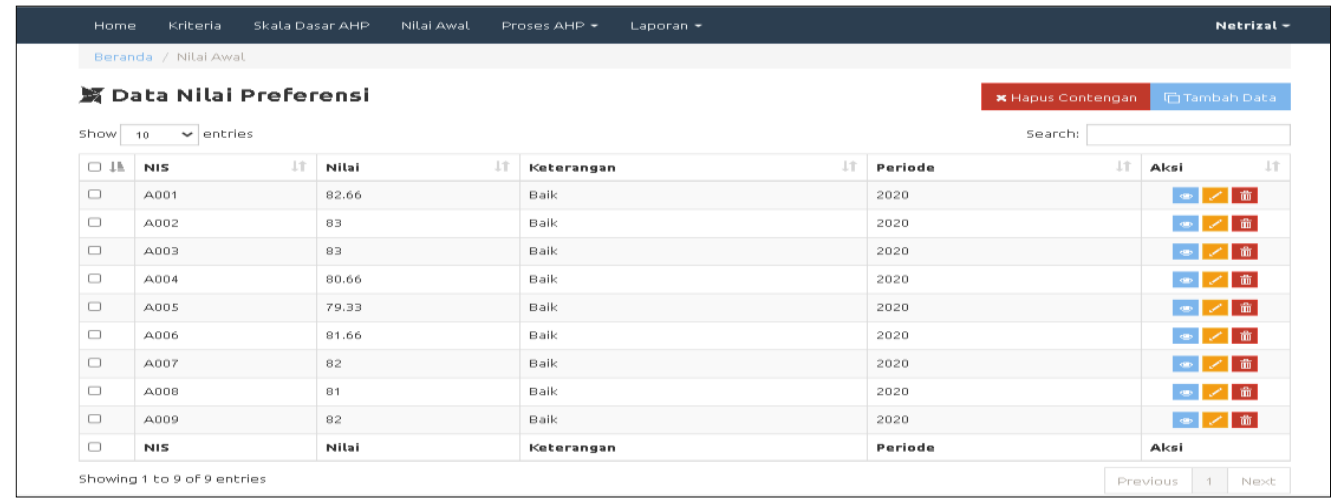

Gambar 3. Tampil Data Preferensi

Asnawati, Copyright (C)2021, MIB, Page 751 
JURNAL MEDIA INFORMATIKA BUDIDARMA

Volume 5, Nomor 2, April 2021, Page 746-755

ISSN 2614-5278 (media cetak), ISSN 2548-8368 (media online)

Available Online at https://ejurnal.stmik-budidarma.ac.id/index.php/mib

DOI 10.30865/mib.v5i2.2918

Seperti terlihat pada gambar 3 tersebut diatas, merupakan tampilan halaman yang digunakan untuk menampilkan nilai preferensi yang telah dimasukkan ke dalam sistem. Disamping itu, terdapat tombol Tambah Data, Edit Data dan Hapus Data yang memilki fungsi Tambah data untuk menambahkan data-data berupa nilai preferensi ke dalam sistem, Edit Data digunakan untuk memperbaiki data yang salah dan Hapus Data yang digunakan untuk menghapus data yang ada di sistem.

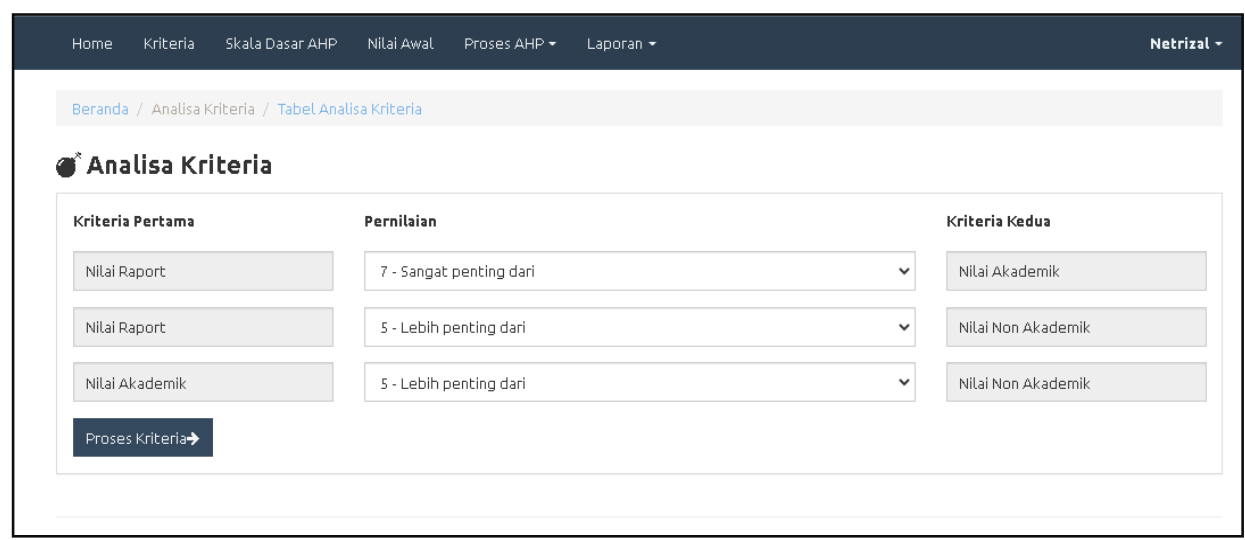

Gambar 4. Analisa Kriteria

Seperti terlihat pada gambar 4 tersebut diatas, merupakan tampilan halaman yang digunakan untuk menampilkan analisis kriteria dari masing-masing kriteria yang dibandingkan dengan kriteria yang lain sebagai proses penyeleksian metode Analytical Hierarchy Process (AHP).

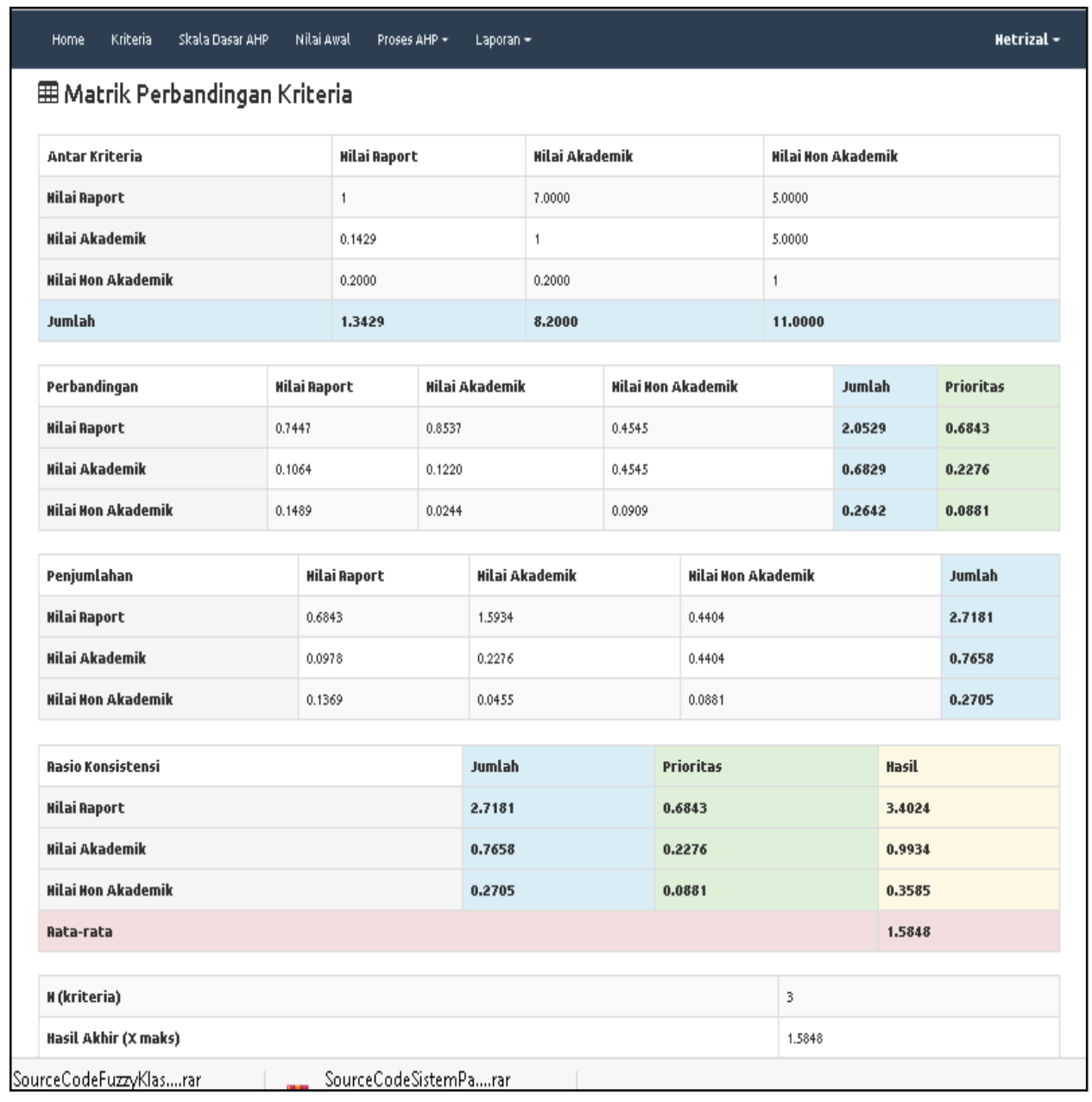

Gambar 5. Matrik Perbandingan Kriteria

Seperti terlihat pada gambar 5 tersebut diatas, merupakan tampilan halaman yang digunakan untuk menampilkan matrik perbandingan terhadap data-data yang dibandingkan sesuaii dengan kriteria yang dipilih sebagai proses penyeleksian SP Analytical Hierarchy Process (AHP) pada Sistem Pendukung Keputusan. 
JURNAL MEDIA INFORMATIKA BUDIDARMA

Volume 5, Nomor 2, April 2021, Page 746-755

ISSN 2614-5278 (media cetak), ISSN 2548-8368 (media online)

Available Online at https://ejurnal.stmik-budidarma.ac.id/index.php/mib

DOI 10.30865/mib.v5i2.2918

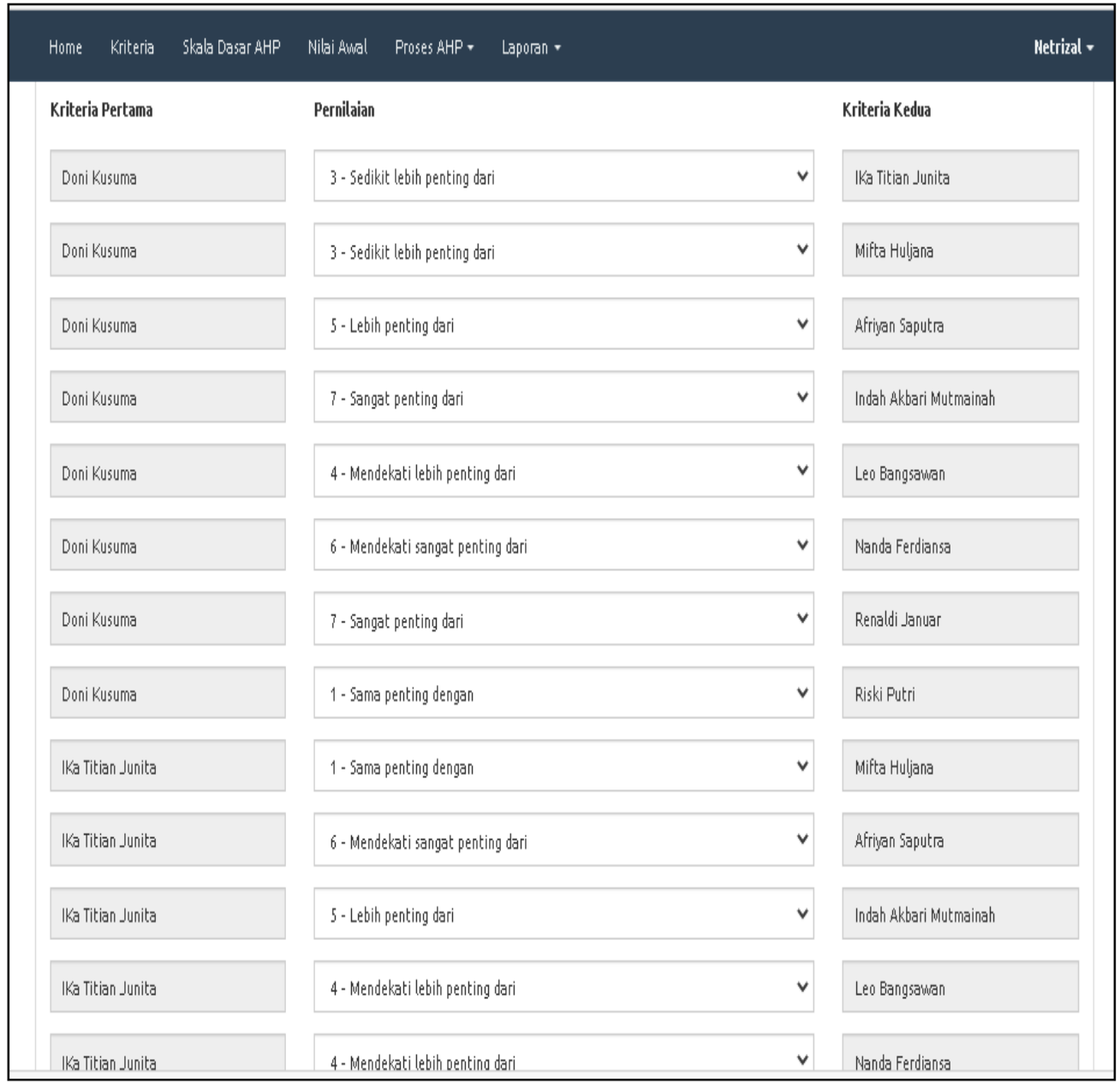

Gambar 6. Perbandingan Data Siswa

Seperti terlihat pada gambar 6 tersebut diatas, merupakan tampilan halaman yang digunakan untuk menampilkan proses perbandingan antar siswa berdasarkan penilaian dari masing-masing kriteria yang dibandingkan dengan kriteria yang lain sebagai proses penyeleksian metode Analytical Hierarchy Process (AHP).

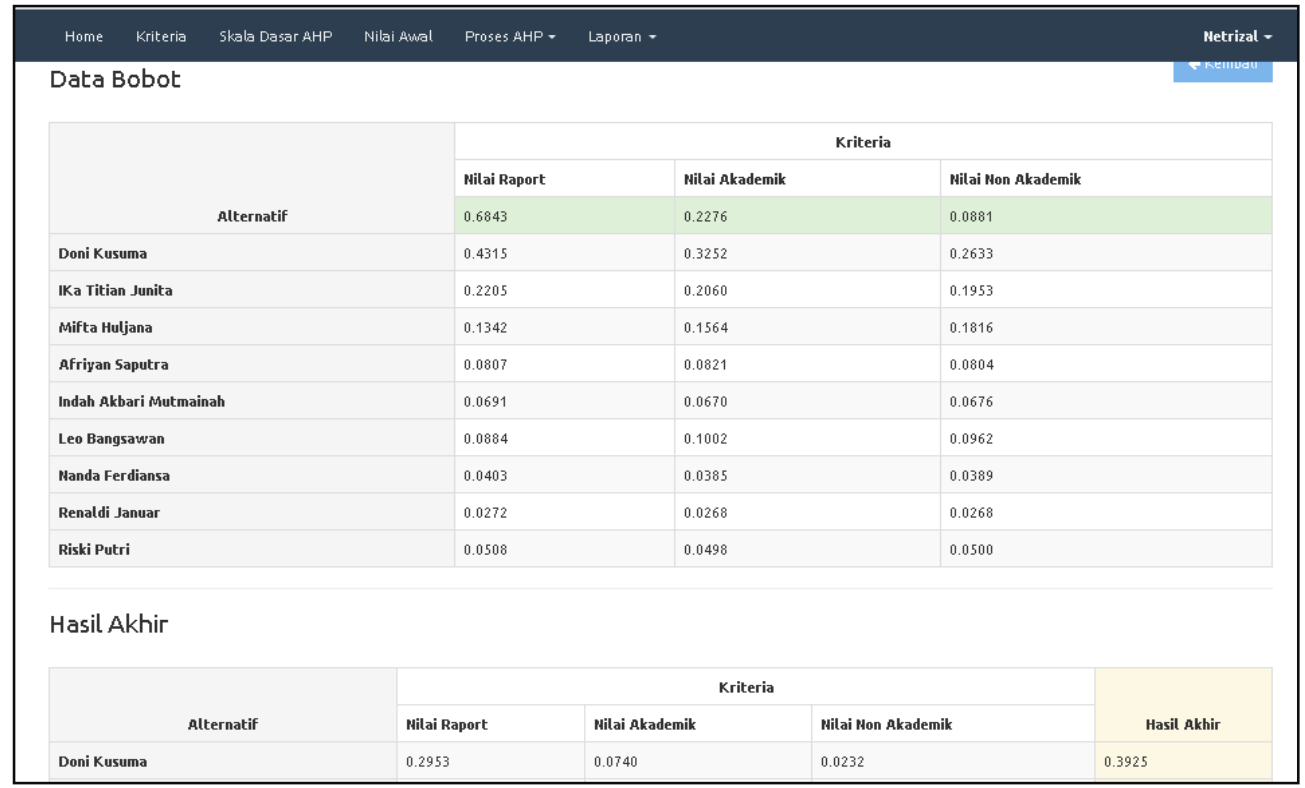

Gambar 7. Hasil Pembobotan 
Seperti terlihat pada gambar 7 tersebut diatas, merupakan tampilan halaman hasil seleksi siswa berdasarkan kriteria yang dipilih sebagai proses penyeleksian metode Analytical Hierarchy Process (AHP).

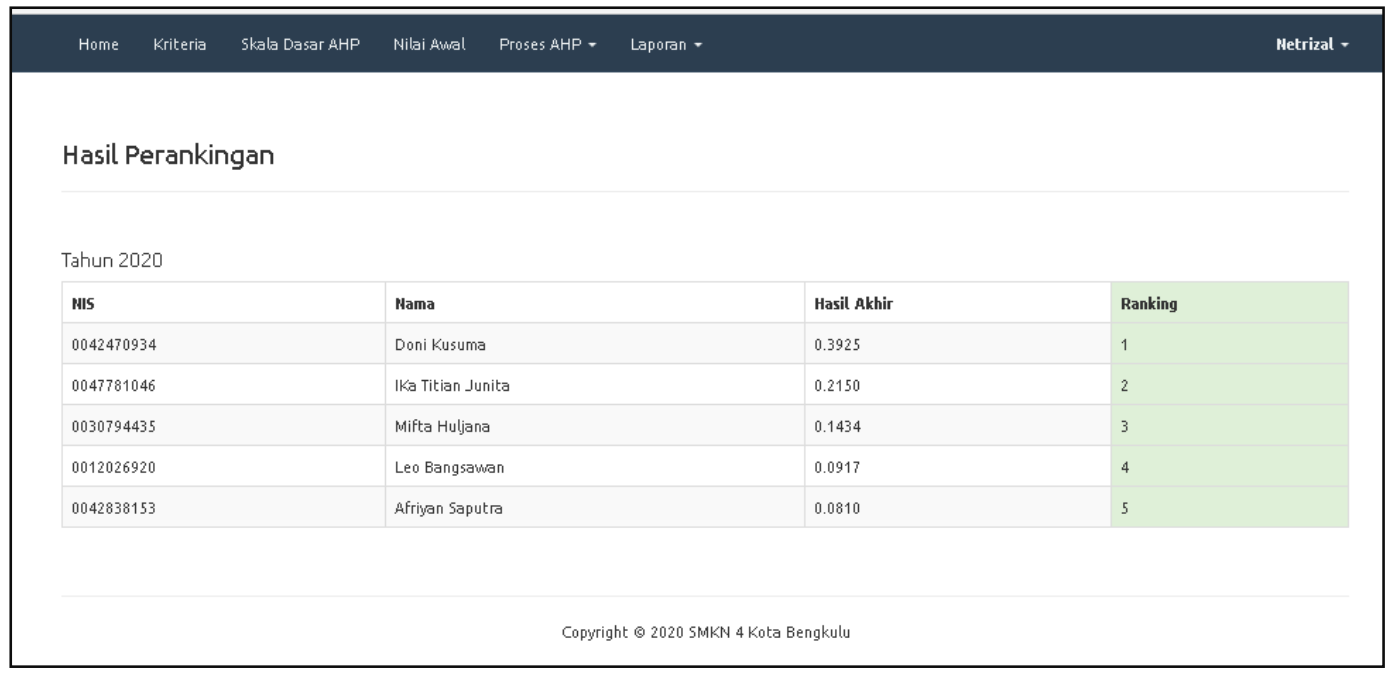

Gambar 8. Hasil Perangkingan

\section{KESIMPULAN}

Berdasarkan hasil penelitian dan pembahasan pada Sistem Pendukung Keputusan (SPK) penerima beasiswa komite sekolah menggunakan metode Analytical Hierarchy Process (AHP) di SMKN 2 Kota Bengkulu, diperoleh kesimpulan: 1) Metode Analytical Hierarchy Process (AHP) dapat dijadikan solusi alternative sistem bagi pimpinan dalam menentukan siswa penerima beasiswa komite sekolah. 2). Penggunaan metode Analytical Hierarchy Process (AHP) dalam Sistem Pendukung Keputusan (SPK) akan menghasilkan siswa yang betul-betul berhak mendapatkan beasiswa berdasarkan kriteria-kriteria yang telah ditentukkan. 3). Penggunaan metode Analytical Hierarchy Process (AHP) diperoleh perangkingan S1, S2, S3, S4 dan S5.

\section{REFERENCES}

[1] Anne Ahira, "Beasiswa Arti Tujuan dan Syaratnya", Artikel diakses pada tanggal 12 Maret 2021 dari http://www.anneahira.com/beasiswa.htm.

[2] Permendikbud Nomor 75 Tahun 2016 tentang "Komite Sekolah"

[3] C. Budisaputro. 2018. Analisa Perancangan Sistem Pendukung Keputusan Penentuan Penerima Beasiswa Dengan Metode AnalyticalHierarchy Process(Studi Kasus: STIKES Bhakti Husada Mulia), Journal of Computer and Information Technology, vol.1, no. 2, hal. 52 -56, 2018

[4] Putri Alit Widyastuti Santiary, Putu Indah Ciptayani, Ni G.A.P. Harry Saptarini, I Ketut Swardika, Sistem Pendukung Keputusan Penentuan Lokasi Wisata Dengan Metode Topsis, Jurnal Teknologi Informasi dan Ilmu Komputer (JTIIK) Vol. 5 No.5 621-628, Okt 2018.

[5] Al Fath Riza Kholdani, Desy Ika Puspitasari, Tri Wahyu Qur;ana, Rancang Bangun Sistem Pendukung Keputusan Pemilihan Perumahan Dengan Metode AHP dan GIS, Jurnal Technologia Vol. 10 No.2 Apri-Juni 2019.

[6] Julia Purnama Sari, Mochammad Yusa, Penentuan Karyawan Terbaik Pada Collection PT.Panin Bank Menggunakan Metode Smart, Jurnal Pseudocode Vol.VII No.2 September 2020.

[7] Ernawati, Nur Aeni Hidayah, Elvi Fetrina. Rancang Bangun Sistem Pendukung Keputusan Kenaikan Jabatan Pegawa Dengan Metode Profile Matching, Jurnal Sistem Informasi, 10 (2) 127-134 2017.

[8] Hairani. 2020. Kombinasi Metode AHP-Topsis Untuk Rekomendasi Penerima Beasiswa SMK Negeri 2 Matararam Berbasis Sistem Pendukung Keputusan. Jurnal Tekno Kompak, Vol 15 No.1 2020.

[9] Ibnu Dwi Lesmono. 2020. Sistem Pendukung Keputusan Untuk Menentukan Beasiswa pada SMA Panca Karya Tangerang Dengan Metode Profile Matching, Vo. 8 No.1 2020.

[10] Yunika Renatalia dkk, 2020, Sistem Pendukung Keputusan Pemilihan Program Studi Menggunakan Metode Profil Matching, Jurnal DIGIT, Vol.10 No.2 November 2020.

[11] Istiqoomatun Nissa dan Arief Wibowo. 2020. Penentuan Dosen Terbaik Menggunakan Metode Analytical Hierarchy Process (AHP) dan For Order By Similarity To Ideal Solution (TOPSIS)Studi Kasus: Akademi Teknologi Bogor, Jurnal Explore IT, 12 (2) 2020.

[12] Kusrini, Konsep dan Aplikasi Sistem Pendukung Keputusan, Andi, Yogjakarta,

[13] Rinianty., dan Sukardi. 2018. Sistem Pendukung Keputusan Penerimaan Karyawan Menggunakan Metode SAW Pada CV. Green Adversiting. Jurnal CCIT. Vol. 11 nomor 1, Februari 2018.

[14] Sudrajat, Budi. 2018. Pemilihan Pegawai Berprestasi dengan Menggunakan Metode Profile Matching. Jurnal Sinkron. Vol. 3 nomor 1, Oktober 2018.

[15] Supriadi, Apip dkk, Analytical Hierarchy Process (AHP) Teknik Penentuan Strategi Daya Saing Kerajinan Bordir, Yogyakarta: CV. Budi Utama Deepulish. 
JURNAL MEDIA INFORMATIKA BUDIDARMA

Volume 5, Nomor 2, April 2021, Page 746-755

ISSN 2614-5278 (media cetak), ISSN 2548-8368 (media online)

Available Online at https://ejurnal.stmik-budidarma.ac.id/index.php/mib

DOI 10.30865/mib.v5i2.2918

[16] Amalia, Rizky Multi dan Dwi Yuni Utami. 2018. Pemberian Reward Berdasarkan Penilaian Kinerja Karyawan Dengan Metode AHP Pada PT. Anugerah Protecindo. Jurnal Ilmu Pengetahuan dan Teknologi Komputer. Vol. 3, No. 2, Februari 201

[17] Tiya, Noviyanti. 2019. Sistem Penunjang Keputusan alam Penerimaan Beasiswa PPA Menggunakan Metode Analytic Hierarchy Process(AHP)(Studi Kasus: Universitas Gunadarma). Jurnal Ilmiah Teknologi dan Rekayasa, Volume 24 No.1 April 2019. 